Evidence $\&$ Policy $\cdot$ vol $12 \cdot$ no $3 \cdot 405-30 \cdot$ c C Policy Press 2016 • \#EVPOL

Print ISSN $17442648 \cdot$ Online ISSN 1744 2656 • http://dx.doi.org/10.1332/174426416X14700793045951

This article is distributed under the terms of the Creative Commons Attribution-NonCommercial 4.0 license

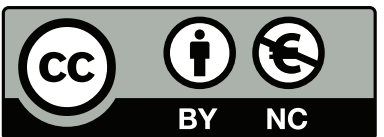

(http://creativecommons.org/licenses/by-nc/4.0/) which permits

adaptation, alteration, reproduction and distribution for non-commercial use, without further permission provided the original work is attributed.

The derivative works do not need to be licensed on the same terms.

SPECIAL ISSUE • Advancing evidence-informed sustainable development policies: innovative approaches addressing the science-policy interface

\title{
research
}

\section{Concepts and practices for the democratisation of knowledge generation in research partnerships for sustainable development}

\author{
Cordula Ott, cordula.ott@cde.unibe.ch \\ Centre for Development and Environment, Switzerland \\ Boniface Kiteme, b.kiteme@africaonline.co.ke \\ Centre for Training and Integrated Research in ASAL Development, Kenya
}

In response to the development and climate crisis of the Anthropocene, world leaders at the 2015 UN Sustainable Development Summit in New York have reconfirmed the urgency of a sustainability transformation. This paper shows how a strong conceptualisation of sustainability can guide scientists in contributing to this transformation. The Eastern and Southern Africa Partnership Programme (1999-2015) offers experiences in framing and implementing research as a transdisciplinary future-forming process. Its procedural, reflexive programme design proved adequate to support the democratisation of knowledge generation. This fostered evidence-based contextualised knowledge and corresponding institutions, and strengthened the future-forming capacity of all partners involved.

key words sustainability science $\cdot$ transdisciplinarity $\cdot$ deliberative democracy $\cdot$ case study

To cite this article: Ott, C, Kiteme, B (2016) Concepts and practices for the democratisation of knowledge generation in research partnerships for sustainable development, Evidence $\mathcal{E}$ Policy, vol 12, no 3, 405-30, DOI: 10.1332/174426416X14700793045951

\section{Alleviating the burden of the poor}

Poverty alleviation has intrinsically motivated the establishment of global and national development agencies and initiatives, and it continues to be their overarching goal (UN-DESA, 2012; ISSC/UNESCO, 2013; UN, 2015). In these efforts, research for development has the task of providing robust evidence-based knowledge for informed decision making. But since the framing of the sustainable development 
paradigm in the so-called 'Brundtland Report' Our common future (WCED, 1987) and its endorsement at the 1992 Earth Summit in Rio, the nature and pathways of development cooperation and research have become highly contested, increasingly complex, and increasingly confused (Springett, 2005; Sneddon et al, 2006; Waas et al, 2011). Concrete efforts and successes have faded into an amalgam of uncoordinated and frequently conflicting strategies that Dryzek and Stevenson $(2011,1868)$ found occupying the space between mainstream sustainability and green radicalism. Despite the omnipresence of sustainability as a buzzword, business as usual has persisted, social and economic disparities are growing worldwide, and humanity is on the verge of overstepping planetary boundaries. At the 2015 UN Sustainable Development Summit in NewYork, world leaders have responded to these challenges by endorsing the Agenda 2030 for Sustainable Development with its 17 Sustainable Development Goals (SDGs) (UN, 2015). By doing so, they have reconfirmed the primacy of the sustainability paradigm and the urgency of a sustainability transformation.

It is thus time to find ways out of the confusion and arbitrariness of current development policy and practice, and to build up momentum for change. The intense debate teaches us that reflecting on our epistemological background as scientists and researchers is essential in identifying effective contributions to sustainable development (van den Hove, 2007; Cornell et al, 2013; Stöckli et al, 2012; Gergen, 2015; Kläy et al, 2014). While elaborating on a strand of discussion launched by the American sociologist Howard S Becker half a century ago, Warren and Garthwaite (2015, 225f) emphasise that in today's geopolitical and academic context, the demand has increased for us as scientists to reflect on and decide whose side we are on and who we serve and write for. In other words, we have to clarify the normative position we hold as knowledge producers, as it also defines what knowledge we produce, how we produce it, and to whom we are accountable (Biermann and Gupta, 2011; Waas et al, 2011; Wiesmann etal, 2011a). In fact, such clarification is becoming even more crucial in view of the increasing commodification of research and the growing pressure for academics to prove their efficiency, impact, and societal relevance (Warren and Garthwaite, 2015; Stewart, 2015). Clarifying our normative position will help identify new roles for scientists in organising the science-policy interface and enhancing evidence-informed decision making for a sustainability transformation (van den Hove, 2007; Jäger, 2009; Naustdalslid, 2011; WBGU, 2012; Gergen, 2015; Spruijt et al, 2014). More so, it can guide us in revitalising, by means of our research, the transformative potential of a more radical construction of sustainable development (Dedeurwaerdere, 2014).Advancing a true sustainability transformation requires responsible leadership, including on the part of scientists (WBGU, 2011). This is an ethical position. Sustainability scientists propose to assume leadership by building on the overarching idea that all members of the human society are entitled to both a just share of resources and an equal voice in the joint organisation of a sustainability transformation (Gallopín et al, 2001; Nowotny et al,2001; UNESCO, 2005; UNDP, 2011). While they acknowledge that science and society have to collaborate more equitably in framing and implementing sustainable development, the reconceptualisation and organisation of effective interaction between scientific actors, policymakers, and civil society remains a major topic of discussion (Harding, 2012). Nevertheless, sustainability scholars are steadily making headway in underpinning and organising a transformation of science towards new deliberative forms of science-society interaction (Sneddon et al, 2006; Kemp et al, 2007; Dryzek 2009; Dryzek and Stevenson, 2011; for an overview see Spruijt et al, 2014). After 
more than three decades of pluralistic practice and an intense discourse, we can draw on a multitude of experiences, reviews, and syntheses underpinning an emerging sustainability science (see, for example, Spangenberg, 2011; Wiesmann et al, 2011a; Biermann et al, 2009; Schroeder, 2014).

This leads to our approach in this paper: we advocate a true sustainability transformation to advance North-South development cooperation and research.The main question is which conceptual and practical features are supportive in framing and implementing research for sustainable development so that it can advance efforts to reduce poverty and enhance equity while promoting efficient use of natural resources. To inform our analysis, we first recall some essentials of the sustainability paradigm, reflect on current theory and practice in science-society interaction, and conceptualise transformative research. On this basis, we then draw on practices and experiences from the Eastern and Southern Africa Partnership Programme (ESAPP), which we consider to be a unique case of transformative research. This has several reasons: When ESAPP was framed in the late 1990s, sustainability science was in its infancy. Having lasted from 1999 to 2015, ESAPP is a rare case of a completed long-term transdisciplinary North-South research programme. Furthermore, in bringing together partners from Switzerland, Kenya, Ethiopia, Tanzania, Madagascar, Mozambique, and Eritrea, it was active at a mesolevel where long-term transdisciplinary experiences are rare (Wiesmann et al, 2011a). Building on the legacy of decades of North-South collaboration in predecessor programmes, ESAPP engaged in research that fostered the democratisation of knowledge and knowledge generation, and expanded its empirical base in more than 300 small research projects. In a final publication entitled Highlights from 15 Years of Joint Action for Sustainable Development, ESAPP partners offer substantial insight into ESAPP's research and outcomes (Ehrensperger et al, 2015). The publication is a major reference for the present paper, in which we complementarily investigate how the programme organised its partnership-based research, and reflect on its implementation, adaptation, and learning processes.

Methodologically, our analysis builds on a systematic review of ESAPP's internal documentation - credit proposals, annual reports, annual intermediate reports, advisory board minutes, evaluation reports, contracts, and internal material from partner institutions and governments - as well as on informal interviews, participatory observation, and our own involvement in research activities. The focus is on features enabling mutual exchange, co-production of knowledge, and learning between scientists, policymakers, and actors from civil society - including places of exchange, actors and networks, institutional arrangements, thematic clusters, as well as tools and products. These features are enabling to the extent to which they expand the deliberative capacity of the programme qualified as a deliberative system (Dryzek, 2009; Dryzek and Stevenson, 2011) and provide - 'from the bottom up' and under the networks' guidance - alternative and effective development pathways (Ostrom et al, 2007). Looking through a democratic lens enables us to detect how the programme framed knowledge and evidence, developed new roles to support effective science-society interaction, and responded to the manifold challenges in managing the science-policy interface (van den Hove, 2007; Wiesmann et al, 2011a; Sarkki et al, 2015). It provides a procedural understanding of the programme's performance that goes beyond standard evaluations. Moreover, it deepens insight into leverage for institutional anchoring and transformative power (Garud and Gehmann, 2012). 


\section{Framing transformative research}

\section{The epistemological roots of conflicting development paradigms}

Authors like Hedlund-de Witt (2014) and Tàbara and Chabay (2013) elucidate how different worldvieus shape our understanding of the concept of sustainable development. They also further underline the need for clarification of our epistemological background and for more reflexive and inclusive forms of policymaking. A first revealing step towards such clarification is to recall the context in which the sustainability paradigm emerged and - as proposed by Sneddon and colleagues (2006) - to analytically distinguish between today's two ruling paradigms: the paradigm of growth grounded in the tradition of a pre-Brundtland world, and the paradigm of sustainable development framed for a post-Brundtland world. In the pre-Brundtland tradition, development policy has been guided by the paradigm of delivering aid and sharing benefits that economic growth generates in rich countries. Deeply rooted in humanitarian norms and religious beliefs, alleviating the burden of the poor has commonly been held to be a self-evident goal. It implies a North-to-South transfer of capital, goods, technologies, and knowledge and a one-way model of transfer of scientific and technological solutions from researchers to decision makers (Cash et al, 2006; Harding, 2012). Such propositions harbour dangers: their advocates run the risk of implicitly accepting a dual world with 'rich' and 'poor' as categories of eternal validity (Mäder and Schassmann, 2012), and of justifying philanthropic and paternalistic sharing as adequate and sufficient means to achieve a better world (Harding, 2012). These approaches rely on capitalistic growth, technological advancements, and exploitation of the world's stock of natural resources. Neglecting structural causes of unequal access to resources, power, and decision making, they are doomed to perpetuate inequality, poverty, and dependency (Spangenberg, 2011, 278).

In contrast, sustainability as the guiding paradigm for a post-Brundtland world was meant as a corrective to the previous paradigm of growth and transfer, which was now considered to substantially aggravate the environmental and development problems it had been intended to solve (Cash et al, 2006; Naustdalslid, 2011). Economic shocks and ecological decline in the 1970s and early 1980s had clearly exposed the limits of economic growth - and welfare - in alleviating poverty and disparities (WCED, 1987; Harding, 2012). It is widely acknowledged that the original conceptualisation of sustainable development was vague - with dissent about this being necessary, supportive, or counterproductive (see Hedlund-de Witt, 2014). But the point of interest here is a considerable consensus among sustainability scholars on the original conceptualisation's transformative potential (Dedeurwaerdere, 2014). Building on the intrinsic link between development, equity, and nature, the sustainability paradigm comprises a radically new normativity (Waas et al, 2011; Wiesmann et al, 2011a). We consider the original 'magic triangle' of sustainable development to be a powerful innovation: By connecting the three dimensions of ecology, society, and the economy in an integrative way and drawing attention to their interdependency and interplay, it breaks the predominance of the economy as the main pathway for solving problems (Cash et al, 2006; UN-DESA, 2012). No matter how many dimensions (culture, time, governance, and so on) scholars propose to include in the original triangle representing them, for example, in diverse nested models (Carter and Moir, 2012) - the basic challenge lies in integrating and balancing the dimensions in view of 
the dilemmas, trilemmas, and polylemmas existing between them. We also regard the premise of equity as a strength, as it clarifies that development can only lead to real progress if it comprises intra- and intergenerational equity. Entitling everybody to a just share of resources and an equal voice opens the field for efforts to change existing disparities, power structures, and decision-making processes, and it implies that scientists must reconsider the nature of expertise and give up primacy in the domain of knowledge (Gallopín et al, 2001; Harding, 2012; Cornell et al, 2013). Scientists and society at large must be engaged in deliberating, deciding on, and legitimising normative issues such as trade-offs, uncertainties and risks, values, goals, and strategies on the way to a desired future (WBGU,2011;2012). This normativity has fundamentally influenced the post-Brundtland world. In global development interventions, the goal of poverty reduction by means of development aid was replaced with the more radical poverty eradication by means of development cooperation, while integrative and people-centred concepts of partnership, participation, empowerment, self-determination, and livelihoods, as well as holistic and gender approaches became prevalent (Wiesmann et al, 2011b).

\section{Lost in the ambiguity of conflicting development paradigms}

But the sustainability paradigm's implementation falls short of expectations. Scholars see a major reason in its original conceptualisation (Hedlund-de Witt, 2014). They argue that the sustainability paradigm itself is inherently ambiguous, enabling the rise of both eco-modernist constructions coupled with weak sustainability, on the one hand, and rare radical constructions of strong sustainability, on the other (Springett, 2005:130f; Sneddon et al, 2006; Waas et al, 2011). System resistance favours weak sustainability with business as usual. Established structures and engineering mindsets easily rule out more radical interpretations. Equity concerns, civil-society agency, and procedural, reflexive, long-term initiatives for system-level change are continuing to be marginalised (Kläy et al, 2014). In science, the tension between weak and strong constructions of sustainability has deepened the divide in the old and wide-ranging discussion on the nature of knowledge and scientific truth (Gergen, 2015). Gergen (2015) argues that - by suppressing contention and fractures - a consensus has nevertheless emerged; he characterises it as reflective pragmatism. While such consensus nurtures a fruitful spirit of pluralism, it also accommodates a stance of 'anything goes' based on an obscure reference to sustainability. As Gergen $(2015,5)$ puts it: 'However, as debates over the grounds of inquiry are abandoned in favor of a pluralist pragmatics, the traditional form of research remains largely unchallenged'. Not surprisingly, then, the meaning of evidence-informed policy and practice, efficiency, and impact is left to rational-technological interpretation while alternative pathways and evidence are conveniently disregarded. Northern dominance and economic, technocratic, and transfer solutions prevail - and fail - in governance and innovation policy and practice (Harding, 2012; Cash et al, 2006; Liverman, 2009; Skoglund and Jensen, 2013). Pushed to the fringes and isolated, equity-oriented concerns are further eroded by financial and social crises and climate change (UNDP, 2011).

The persisting dominance of scientific knowledge is confirmed strikingly in global governance approaches, which - following the Earth Summits in Rio in 1992 and in Johannesburg in 2002 - turned into major experimental fields for science-society interaction. Although alternative framings that aim at organising global scientific 
assessments as collective learning processes have gained ground, the traditional roles ascribed to scientists, the public, and policymakers remain largely unchanged. Scientists are still broadly perceived - and perceive themselves - as being objective and value-free fact-producers for decision makers. However, while science offers models, probabilities, and scenarios, it cannot rule out uncertainties (Liverman, 2009; Naustdalslid, 2011). Some scholars even argue that an increase in knowledge results in additional uncertainty and thus in a loss of capacity to act (Sterman, 2002; Trenberth, 2010; Pindyck, 2013). The integration of the wider public is limited and often instrumental (Lövbrand et al, 2009). Dryzek and Stevenson (2011) illustrate how representatives of developing countries are usually outnumbered and sidelined in global negotiations. Resulting global policies remain top-down, power-driven, and sectoral. While we have access to an enormous amount of synthesised scientific knowledge about how to mitigate and adapt to global change, including climate change, power imbalances and conflicts of interest limit action and thwart coherent governance structures. Despite hundreds of multi-and bilateral agreements, programmes, and institutions, severe dissent in debates - most obvious in the post-Kyoto negotiations - demonstrates the inability of the global community to realise equity-based and effective solutions for a sustainability transformation (Dryzek and Stevenson, 2011, 1865f; Schroeder, 2014). New initiatives are haunted by the paradigms of growth and market liberalisation that contradict the principle of equity and create new NorthSouth tensions and bargaining (Skoglund and Jensen, 2013). Such experiences confirm that scientists have to remain in charge of producing evidence-based knowledge for decision making. But they are also responsible for, and capable of, supporting true integration of civil society into knowledge generation and decision making, ensuring that adequate account is taken of the contexts in which measures are to take effect, and developing societies' capacities to produce and use advanced knowledge (Naustdalslid, 2011; Arocena et al, 2015).

\section{Sustainable development as a democratic principle}

Since the turn of the millennium, leadership towards a sustainability transformation has been taken over by an emerging sustainability science (Lubchenco, 1998; Kates et al, 2001; Nowotny et al, 2001; Gallopín et al, 2001). Working out of niches, scholars are establishing sustainability networks and institutions that transcend disciplinary and scientific boundaries. They illuminate the epistemological background of research for sustainable development (Wiesmann et al, 2011a; Skoglund and Jensen, 2013) and bring together long-standing participatory, democratic, and emancipatory traditions in science and society (Hirsch Hadorn et al, 2008; Harding, 2012; Olsson et al, 2014; Haller et al, 2016; an overview is provided in Spangenberg, 2011; Spruijt et al, 2014; Kläy et al, 2014). Despite its diversity, the sustainability science community is characterised by considerable consensus: sustainability scholars generally strive for a strong conceptualisation of sustainable development (Dedeurwaerdere, 2014). According to Waas and colleagues $(2011,1645)$, 'sustainable development as a concept possesses a precise and unambiguous meaning'. Its original conceptualisation builds on four fundamental principles which form its 'bottom line': normativity, equity, integration, and dynamism 'represent the interpretational limits of the concept and are essential to sustainability no matter which view and interpretation is employed' (Waas et al, 2011, 1657). But, because 'sustainability emerges as a horizon to be approached but never 
reached' (Garud and Gehman, 2012, 992), research is a future forming practice that must accommodate pluralism (Gergen, 2015). By attaching greater value to equity, scholars nurture the transformative and emancipatory seed inherent in the concept of sustainability. They work to relink human rights with development, and aim to advance inclusive and sustainable economic development with a view to creating an environmentally safe and socially just space for humanity (Jäger, 2009; van Egmond and de Vries, 2011; Dryzek and Stevenson, 2011). The community also agrees on the need to frame earth system governance in an innovative way (Biermann et al, 2009; Lövbrand et al, 2009). The focus on equity requires reframing knowledge and reorganising knowledge generation and the science-society interface (Hirsch Hadorn et al, 2006; Pohl and Hirsch Hadorn, 2007; van den Hove, 2007; Jäger, 2009; Stock and Burton, 2011), and it encourages us to revise our traditional role and (self-) conception as researchers (Tàbara and Chabay, 2013;WBGU,2012; Cornell et al,2013). This has led to a new and more democratic conceptualisation of knowledge and of the relationship between science and society (Welp et al, 2006; Jäger, 2009; Dryzek, 2009; Dryzek and Stevenson, 2011; Hendriks 2009; WBGU, 2012, Cornell et al, 2013; Spruijt et al, 2014; Arocena et al, 2015). The United Nations Educational, Scientific and Cultural Organization (UNESCO, 2005) framed the development of knowledge societies based on the democratisation of knowledge and knowledge generation as a strategic goal. This provided a strong impetus for a radical construction of sustainable development 'as part of the deliberative turn to a more discursive theory of democracy' (Bryzek, 2000, in Springett, 2005, 130). Sustainability scholars no longer perceive their role as that of 'value-free', 'objective', or 'neutral' fact producers, but conceive of themselves as reflective, value-oriented, and responsible knowledge brokers and agents for sustainable development (Hering, 2016). More and more researchers are willing to give up primacy in the sphere of knowledge. They engage in action research, integrating knowledge systems and actors outside the scientific community and triggering joint learning processes in which they assume the dual role of generating knowledge and strengthening civil society for balanced exchange (Rist et al, 2007; Kristjanson et al, 2008; Wiesmann et al, 2011a; Haller et al, 2016). According to Springett $(2005,129)$, constructing sustainable development as a democratic principle counters the economic capture of the sustainability concept. Such a construction calls for a society based on inclusive participatory democracy - in other words, on deliberate democracy in which actors participate in a communicative process and influence collective decisions (Hendriks, 2009, 175; Dryzek and Stevenson, 2011).Arguing that deliberation strengthens the environmental performance of states, Dryzek $(2009,1382)$ frames their deliberative capacity as 'the extent to which a political system possesses structures to host deliberation that is authentic, inclusive, and consequential'. Dryzek and Stevenson $(2011,1867)$ further expand deliberative democracy into a deliberative system with public space, empowered space, transmission, accountability, meta-deliberation, and decisiveness as elements; they intend this as an analytical framework which is also suited for the analysis of governance networks and earth system governance.

\section{Research as 'future forming'}

What does this mean with regard to operationalising sustainable development in transdisciplinary practice? Surely, it means that we need to strengthen the deliberative capacity of our research - understood as a political system - by means of adequate 
research structures and procedures (Pohl et al, 2008; Dryzek and Stevenson, 2011:1872; Olsson et al, 2014). The focus of research at the science-policy interface thus needs to shift from the outcome to the processes of societal knowledge generation: to experimentation, learning, and constant change in an adaptive governance approach (Dietz et al, 2003; van den Hove, 2007;VISION RD4SD, 2013). Such science-society interaction requires new structures that accommodate democratic features: for example equity, inclusiveness, accountability, legitimacy, and deliberation, as proposed by Biermann and Gupta (2011), or iterativity, credibility, relevance, and legitimacy, as proposed by Sarkki and colleagues (2015). According to Gergen, 'research as a future forming practice' (2015, 6) replaces 'the captivating gaze on the world as it is with value based explorations into what it could be' $(2015,1)$. This understanding implies that we must develop a sustainable future in procedural and experimental societal processes which we constantly benchmark against our epistemological background and achievements as scientists and researchers devoted to poverty alleviation and sustainable development (Wiesmann et al, 2011a; Garud and Gehmann, 2012; KPFE, 2014). Such reflection - if it takes place - is commonly limited, for example to formal monitoring and evaluation systems in which impact and efficiency is measured exclusively against preset goals. In such systems, '... reflection moves from issues of philosophic grounding to social utility' (Gergen, 2015, 4). By contrast, in collaborative processes or action research, evidence is reconceptualised as it acquires meaning in the communicative process and is constantly applied and reassessed in varying contexts (Kemp et al, 2007; Spruijt et al, 2014; Warren and Garthwaite, 2015). As Higgins and colleagues (2014, 492) put it: "The reality... is that all evidence will be somehow partial, provisional and contingent and thus needs to be used as part of an ongoing process of evaluation, learning, adaption and adoption'.

But deliberation alone will not lead to sustainable development as long as knowledge and power gaps restrict meaningful participation. This underlines researchers' dual role of providing evidence while simultaneously empowering actors and institutions as agents of change (Wiesmann et al, 2011a). In transdisciplinary practice, researchers open up the processes of scientific knowledge generation to non-scientific actors and expand human and institutional capacity for sustainable development by means of education and training, joint research and learning processes, as well as knowledgebrokering activities and products (Hurni and Wiesmann, 2004; Dryzek, 2009; Cornell et al, 2013; Head, 2015; Hering, 2016; Stewart, 2015). They also further develop ways of coping with conceptual and operational challenges or necessary trade-offs at the science-policy interface (Wiesmann et al, 2011a; Sarkki et al, 2015). Indeed, progress in the democratisation of science has been observed in recent years (UNESCO, 2010). Sustainability science, with its transdisciplinary methodologies, provides a wealth of approaches, especially bottom-up and contextualised ones, that are capable of broadening options for action, balancing disparities, and generating sustainable development pathways (Kemp et al, 2007; Pohl et al, 2008, Hirsch Hadorn et al, 2008; Rist et al, 2007; Haller et al, 2016). Sustainability scholars are making headway on transdisciplinary concepts and practice by synthesising and theorising mainly qualitative field data on a metalevel (Biermann et al, 2009; Jäger, 2009; Hendriks, 2009; Spruijt et al, 2014). But sustainability science is fairly young, and it is substantially restricted by the unfavourable institutional fabric and dominant narratives (Spangenberg, 2011; Kläy et al, 2014). Transdisciplinary practice often remains isolated or unreported, and experiences of long-term transdisciplinary practice at a mesolevel are rare (Wiesmann 
et al, 2011a). On the other hand, the diversity in current transdisciplinary concepts and methodologies is splendid. It matches sustainable development's experimental nature and needs to be embraced. But to effectively harness its transformative power and avoid an 'anything goes' development, we also need to nourish common ground (Waas et al, 2011). One way of doing this is to focus on transdisciplinary research practice and build on what works. In the words of Gergen $(2015,12)$, it is ' ... promising to examine current and emerging practices with future forming potential. If such practices can be illuminated in terms of this potential, a new consciousness may be germinated. New and more potent practices may be stimulated'. Let us, then, take a look at a concrete research initiative and its future forming potential.

\section{Organising the democratisation of knowledge in research for sustainable development: a case study}

\section{A first prerequisite: an enabling science-policy interface}

When the Eastern and Southern Africa Partnership Programme (ESAPP, 1999-2015) Wwas framed in the late 1990s, both public involvement in global assessments and sustainability science were in their infancy. At that time, the programme's design was ground-breaking. Relatively small in size (around CHF 1.2 million per year), it was ambitiously launched as an equity-oriented long-term inter- and transdisciplinary North-South research endeavour in the field of sustainable development. Spanning Switzerland and several countries in Eastern Africa, it confronted the challenge of tackling the complexity of a transnational and transcultural science-policy interface. What was it, then, that provided the foundations for such a programme?

Our analysis reveals that the science-policy interface formed in decades of Swiss research experience and partnerships in Eastern Africa was conducive and a prerequisite to ESAPP's design. The programme's developers could build on established and trustful collaborations between research partners and research users in research institutions, donor agencies, governmental offices, NGOs, and civil society in the North and South. Indeed, the programme's design is an outcome of these interactions. First, it was partially a response to demands exposed in the predecessor programmes - mostly the Soil Conservation Research Programme in Ethiopia and Eritrea (1981-1998), the Laikipia Research Programme in Kenya (1984-1998), and the Terre-Tany Programme in Madagascar (1989-1998). Based on their experiences, donors and government offices in the South requested that a new programme should foster integrative research and be better integrated in the host countries' political and scientific landscapes. Second, on the supply side, ESAPP's developers could build on previous work of a loose but lively network of sustainability-oriented scholars and practitioners in Switzerland. This network included representatives from the Swiss Agency for Development and Cooperation, which in 1988 had commissioned the newly founded Centre for Development and Environment (CDE) to help prepare the 1992 Earth Summit in Rio and to translate the normative goals of sustainable development into poverty alleviation policies and practice. It included CDE - ESAPP's mother institution - which had come up with integrative and deliberative concepts and tools focusing on human agency, science-society interaction, and social learning already in the 1990s (Wiesmann, 1994; Wiesmann, 1998, Wiesmann et al, 2011b); and it included representatives from the Swiss Academy of Sciences (SCNAT) and 
the Swiss Commission for Research Partnerships with Developing Countries (KFPE) that collaborated with CDE in drafting a new understanding of knowledge and the role of science in sustainable development (ProClim, 1997; Hurni and Wiesmann, 2004; Stöckli et al, 2012). This context prepared the ground for a shared understanding of ESAPP's mandate in research for sustainable development. The Swiss Agency for Development and Cooperation as the funding institution was not only willing to give the developers considerable leeway for launching ESAPP as a pioneering transdisciplinary programme from the very beginning; it was itself actively involved from the outset. The same is true for government offices in the host countries, who had long been part of the network too.

\section{A second prerequisite: emancipatory epistemological foundations}

The design and the implementation of the new programme were strongly guided by the 11 Principles and 7 Questions proposed by KFPE (Stöckli et al, 2012). Based on their deliberative and democratic nature, they align smoothly with today's state of the art in sustainability science, and they frame research as what Gergen (2015) calls a future forming practice. They gave reason to ESAPP being founded on the three pillars of sustainability, partnership, and transdisciplinarity, and to the programme's adherence to the fundamental democratic principles (see above, Sustainable development as a democratic principle). ESAPP accommodated a strong conceptualisation of sustainable development, and constituted itself as a communicative space (Hendriks, 2009; Higgins et al, 2014) to counteract inequity as well as knowledge and power disparities in its research activities.

The fact that ESAPP's research was organised in line with key principles of more democratised knowledge production, social learning, and institutional development is well reflected, first, in the programme partners' understanding of transdisciplinarity as an integrative approach that brings together scientific and 'non-scientific' (endogenous, cultural) knowledge systems, social and political actors and institutions, as well as different places and scales (Pohl et al, 2008; Stock and Burton, 2011; Wiesmann et al, 2011a). Second, ESAPP applied a concept of knowledge that had also been developed within the Swiss network of sustainability-oriented scientists and practitioners. This concept requires science-society interaction to give meaning to sustainable development by compiling systems knowledge, which describes the subsystem or problem to be addressed ('what is'), target knowledge, which encompasses a shared vision of a sustainable future ('what ought to be'), and transformation knowledge, which describes negotiated measures and pathways to follow ('how to get there') (ProClim, 1997; Pohl et al, 2008; Wiesmann et al, 2011a). Third, ESAPP pursued equity as a structural goal within the partnership itself (Figure 1). Programme management was kept flexible enough to allow for responding to partners' preferences, for increasing their influence and ownership, and for continuously organising research accordingly. Finally, in line with CDE's core competence, ESAPP focused on creating contextualised knowledge about sustainable land management and sustainable regional development. Contextualised knowledge can only be gained and processed together with local actors; this enables it to be robustly coupled to human-environment systems and to support local to global sustainability coherence (Tàbara and Chabay, 2013). 


\section{Figure 1: Diversity of partners in ESAPP's Southern network}

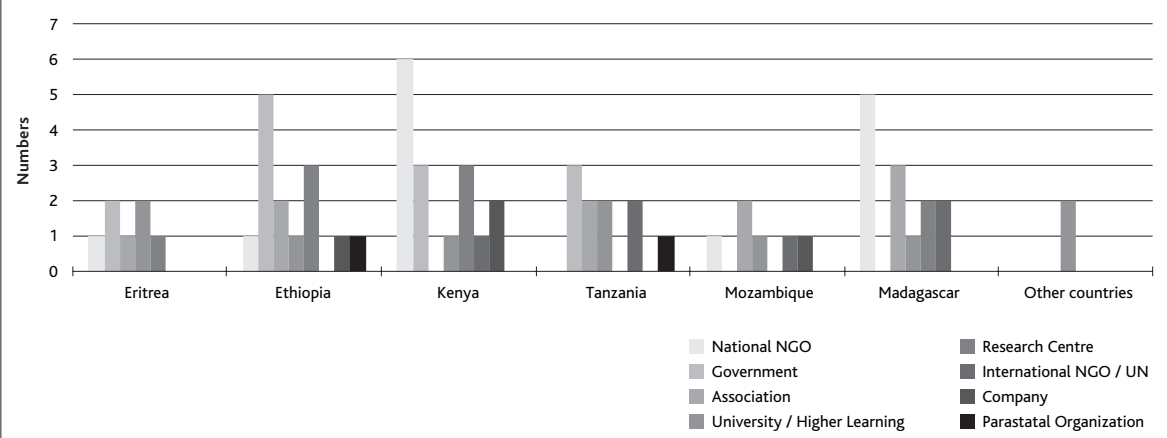

Source: Eastern and Southern Africa Partnership Programme Final Report 2015

\section{A third prerequisite: consistent but adaptive implementation}

An adequate institutional fabric is of utmost relevance in operationalising democratic principles in processes of joint knowlegde generation. Matching approaches that Kemp and colleagues propose for guiding the processes must be '... concerned with the normative orientation of societal processes and seek, to different degrees, to overcome the conflict between long-term imperatives and short-term concerns' (Kemp et al, 2007,89 ). Our analysis reveals that this was indeed what ESAPP pursued in combining an open partnership framework with an adaptive research implementation scheme.The Gatter consisted of three structural approaches designed to foster recursive, reflexive interaction and procedures with consequential programme adaptation (Wiesmann et al, 2011a).Together, they were intended to provide an enabling institutional arrangement for securing coherence, consistency, and Southern agency across all of the programme's research activities. According to Spangenberg (2003, in Spangenberg 2011,282), it is such a 'combination of formal structures and applied, often pragmatic, management that makes the difference for integrated interdisciplinary projects in sustainability science'. ESAPP's three structural approaches were the following:

\section{An adaptive management approach that integrates actors' agency}

Adaptive management approaches have come to be widely accepted in research for development, as they correspond to the open-ended, complex, and risky character of processes of system change, development, or future forming (Dietz et al, 2003; Wiesmann et al, 2011a; VISION RD4SD, 2013). But at the turn of the millennium, applying such an approach was innovative and experimental. Adaptive management approaches take into account that a programme can only partially preset goals and procedures, as its implementation must integrate partners' agency and the programme must thus be accountable to funding agencies as well as to partners and beneficiaries. In the case of ESAPP, adaptive management was expected to provide a stable institutional fabric while allowing core partners to increasingly co-determine and modify institutional structures, research procedures, and goals in response to needs and options arising during programme implementation. 


\section{A dual structure approach that harmonises concepts and action}

In development contexts, people's short-term priorities often override long-term sustainability imperatives. Research for sustainable development is in danger of being biased, either following concepts that fail to adequately capture local realities or - in the case of action research (Gergen, 2015, 16) - being driven largely by local needs without reference to the wider contexts. A frequent, but insufficient approach to accommodating both perspectives is to merely add an action research component to business-as-usual basic research (Kristjanson, 2008). To better integrate need-driven and concept-driven concerns within its transdisciplinary process, ESAPP linked an action research component with a supportive component of basic research and capacity development. The action research component comprised over 300 small-grant priority action projects initiated by local partners alone or in collaboration with researchers. This is where knowledge was co-produced between researchers and local actors whom we understand as agents of change and partners in research. The rationale behind the second component was mainly to underpin knowledge generation and capacity development with concepts and basic research, and to support reflection, learning, and adaptation. The two components were intended to interact, reinforce each other, and eventually reshape the programme.

\section{A contextuality approach that links places and scales}

Global trends continue to threaten ecosystems in contexts where vulnerable rural populations largely depend on natural resource use. Global governance approaches are currently reappraising rural areas, agriculture, and livelihoods of small-scale resource users in developing countries (UNCBD/UNCCD/UNFCCC, 2012). Attempts have been made to compensate rural populations' efforts to use resources sustainably and preserve the global commons (the climate, biodiversity, forests, and others). But without robust knowledge about local human-environment systems, strategies generally remain top-down, sector-specific, isolated, and contradictory. This brings contextualised knowledge - knowledge that is embedded in a specific time, place, and scale and generated in joint processes between scientists and local actors - up high on the global development agenda. But this knowledge must also be generalised, consolidated in databases, and further exchanged if it is to benefit global to local governance. Databases are a key asset for developing countries in formulating self-determined and just national development strategies and in interacting with global development institutions (Haller et al, 2016; Hering, 2016). Thus, at its outset, ESAPP was mandated to further develop the transdisciplinary character of the contextualised knowledge, databases, and partner networks created by CDE's predecessor programmes in Africa, and to make them available for decision-making support and further research.

In the following section we provide examples of how the three structural approaches created the communicative space needed for meaningful and sequential interaction, for the democratisation of knowledge generation, for developing contextualised knowledge, and for enhancing the capacities of people and institutions in the South and North. In doing so, we refer to many of the 24 ESAPP Highlights presented in the programme's final publication (Ehrensperger et al, 2015). 


\section{Processes towards contextualised knowledge and capacity}

\section{Institutionalising joint programme navigation}

ESAPP was a North-funded programme, and was thus North-driven at its inception. The advisory board - the programme's steering body - was composed of representatives of the Swiss Agency for Development and Cooperation as the funding institution, of CDE, and of related Swiss institutions. Southern partners were not represented until 2011. But experiences in the first years emphasised the need especially for Southern core partners to perform a more robust and equal role and ensure research coherence, relevance, and quality for the benefit of the South. Consequently, the programme partners sought to expand the programme's communicative space. In a transnational research programme, this is more than just a logistical challenge: organising joint processes among partners with different cultural backgrounds and varying institutional strength requires time, resources, and mutual trust. In 2006, the partners initiated annual one-week workshops that took place in a different Southern partner country each year. This was a major step in overcoming geographic distance and fostering communication and a common understanding on a regular basis (Highlight 20). These so-called capitalisation workshops immediately became a cornerstone of joint programme management, capacity development, and South-South exchange. Here, ESAPP partners met for intense exchange, data and method sharing, deliberation and self-evaluation, strategic reorientation, and a field excursion. The workshops provided a communicative space for participants to apply and further develop ESAPP managerial tools, settle conflictual issues, and integrate recommendations from regular external programme evaluations. Here, they made necessary changes in the programme's organisational structure and research design. ESAPP's capitalisation workshops can be understood as empowered space within the programme's deliberative system (Dryzek and Stevenson, 2011). Meta-deliberation led to decisions on programme navigation, helped to consolidate the network, and strengthened Southern partners' deliberative capacity and ownership, but it also provided the ground for accountability to the wider public.

\section{Developing an integrative, procedural monitoring and evaluation system}

At the beginning of ESAPP, criteria for selecting small priority action projects - ESAPP's key research unit - were mainly formulated by the Swiss Agency for Development and Cooperation as the funding institution. Correspondingly, monitoring and evaluation mechanisms reflected goals and indicators valued in the North. Fostering its deliberative capacity, the programme gradually established new forms of process benchmarking that integrated Southern partners' perspectives. They combined simple and readily understandable standard formats (such as templates, criteria, logical frameworks, and statistics) and standard procedures (such as advisory group meetings, project-cycle steps, and external evaluations) with reflexive elements (self-evaluation, feedback-loops). In physical or virtual meeting places - from 2006 onwards, especially in the annual capitalisation workshops - partners regularly reflected on the status of the research, with standard formats and field activities providing the necessary background information. Monitoring the impacts of over 300 small projects separately would not have been feasible or economically justifiable. But the 
combination of standard and new reflexive elements in ESAPP's monitoring and evaluation system proved to be a viable, inclusive and consequential alternative. It made it possible to integrate research results as evidence in 'an ongoing process of evaluation, learning, adaption and adoption' (Higgins et al, 2014, 492), and strengthen Southern partners' reflexive capacity in a process of continuous project assessment and adaptation (Kemp et al, 2007; Wiesmann et al, 2011a). Serving as a navigation tool (Stöckli et al, 2012), ESAPP's monitoring and evaluation system was well-suited to the experimental nature of research for sustainable development.

\section{Scaling research results up and out}

The pressure for quick and effective interventions is high in rural development contexts; accordingly, ESAPP was confronted with high numbers of priority action project proposals. In response, the programme partners established a procedure of selection and thematic concentration which ensured a meaningful choice of projects in line with ESAPP's mission, scope, and budget. The procedure secured local responsibility and relevance by means of a preselection done by the coordinators acting as focal points in the respective partner countries. In the annual capitalisation workshops, partners further selected, built upon, and put in sequence projects that showed great promise, grouping them in local research clusters and thematic networks. Eventually, this led to the creation of thematic partnerships between countries which promoted the scaling up and scaling out of results across the whole region. Finally, ESAPP connsolidated its research in ten reference sites, where partner institutions concentrated on context-specific priorities within the region. This process heightened the impact of the research and enabled a meaningful integration not only of disciplinary, interdisciplinary, and transdisciplinary research, but also of approaches from the social sciences, humanities, and natural sciences and technocratic approaches, which are all too often employed separately in development cooperation (Hirsch Hadorn et al, 2008; Harding, 2012) (Highlights 1, 2, 4, 10, 11, 22). Within this institutional setting, Southern partners increasingly acted as knowledge brokers between the programme and local stakeholders, steering research projects and promoting South-South exchange (Figure 2). This made it possible to scale up and scale out research results of more than 300 priority action projects. ESAPP's procedure of selecting, clustering, and sequencing small-grant priority action projects is particularly suitable and relevant for linking micro- with mesolevel contexts and providing the contextualised data needed for global approaches (UNCBD/UNCCD/UNFCCC, 2012) (Highlight 21). Furthermore, action research projects are highly effective when it comes to giving local people a just share and a voice in research activities. Putting projects in sequence enabled long-term collaborative processes with local communities, thus expanding ESAPP as a deliberative system. This is most relevant in contexts where resource use is conflictual and new governance institutions are needed (Highlights 3, 5, 7, 12).

\section{Consolidating and leveraging networks of partners}

ESAPP's long-term involvement made it possible to institutionalise deliberative spaces, interaction, and capacities (Dryzek and Stevenson, 2011; Hendriks, 2009). Partners had time to build close personal ties thanks to the legacies of former research collaboration. The strong commitment of a number of individuals in the North and 
Figure 2: ESAPP's contextuality approach: shared responsibility in steering thematic and place-based research on sustainable land management and sustainable regional development

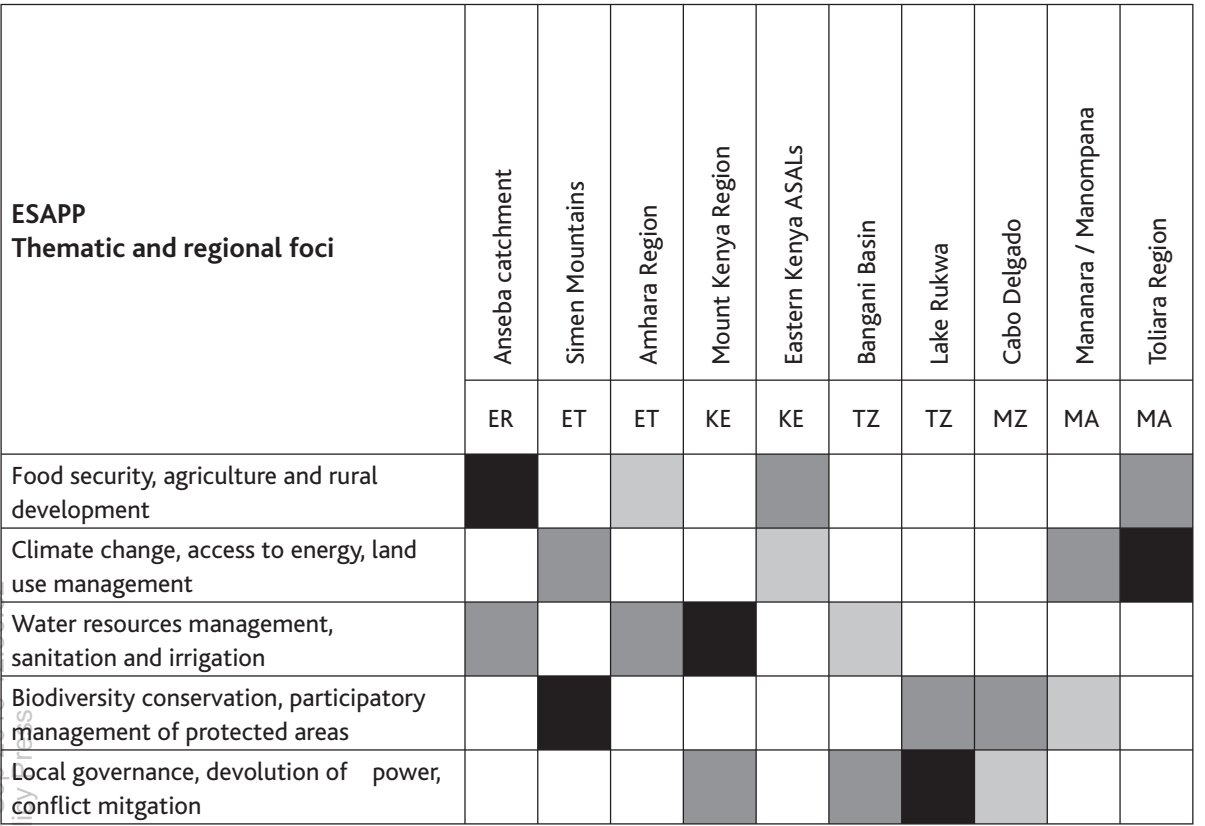

Leading site Key partner $\square$ Participating site

Source: ESAPP Programme Outline for Phase IV, 2011-2013

South, along with mutual respect, trust, and friendship, are key in supporting quality transdisciplinary knowledge generation and the uptake of knowledge and results (Mansilla et al, 2012). In ESAPP, these qualities also facilitated equity and inclusion and strengthened the programme as a deliberative system. A look back reveals that previous research collaborations resulted in the Southern partners having a much stronger voice and agency in formulating and implementing the programme, even at its outset. The founding of the Centre for Training and Integrated Research in Arid and Semi-Arid Lands Development (CETRAD) is a good illustration of Southern agency (Highlight 16). CETRAD was established in 2002 as an institution of the Government of Kenya with a regional mandate. While CETRAD is based on earlier Swiss-Kenyan cooperation and came into existence within ESAPP, the Government of Kenya was a key driver in establishing such a research institution within the government. The Water and Land Resource Centre (WLRC) in Addis Ababa, Ethiopia, established in 2011, has a similar background and structure (Highlight 18). But many other institutions down to the village level also grew out of ESAPP research activities (Highlights 3, 6, 23).

In ESAPP's implementation and learning processes, partners jointly consolidated networks that were initially broad and loose. They transformed network nodes into country-based knowledge hubs capable of designing and implementing contextspecific sustainable solutions. Only strong 'contextualised' institutions that emerge in the research context can ensure firm internalisation of transdisciplinarity and sustainability and reduce the danger of a continuing dependency on Northern 
(financial) input (UNDP, 2011;WBGU, 2011). ESAPP thus fulfilled the demand for transformative science to both generate new knowledge in research partnerships and strengthen civil society through human and institutional capacity development for meaningful participation (Wiesmann et al, 2011a). Southern institutions gradually became more equal partners within the programme, with a corresponding gradual transfer of power and budget. They improved their position within their respective countries and initiated new strategic collaborations and networks. Hundreds of government officials, experts, and researchers increased their contextualised capacity for sustainable development by participating in ESAPP's research, education, and training activities. Today, they form a network of partners across Eastern Africa that has a high future forming potential beyond the programme's lifetime.

\section{Integrative education and capacity development}

While human and institutional capacity development was integrated in all programme activities, ESAPP also made strategic investments in education and academic training for trainees from the North and the South. Most prominently, CETRAD in Nanyuki, Laikipia District, Kenya, developed comprehensive training courses that attracted professionals from research as well as from governmental and non-governmental institutions in Kenya and other countries (Highlight 16). ESAPP supported Mekelle University in Ethiopia in developing curricula, tools, and field courses to educate students and train future trainers in inter- and transdisciplinary research approaches (Fighlight 15). The Water and Land Resource Centre (WLRC) in Addis Ababa is working to further develop ESAPP's database on integrated water resource management, combining this work with capacity development for national staff (Highlight 18). The use of its own base of knowledge and data in education and training enabled ESAPP to continually interrelate and adapt basic research, human and institutional development, and action research. Combining conceptual and capacity development with action research increases the quality of deliberative knowledge generation and social learning. This is innovative and very attractive not only for academia, but also for governmental and non-governmental bodies in the South. Several hundred trainees obtained positions in research institutions or public administrations and continue to strengthen the sustainability network in the South. Such an approach thus empowers national governments to function as the missing link between macro- and microlevels (Haller et al, 2016). Methodologically, the approach gave rise to new tools, including knowledge portals (Table 1). Tools that combine analytical and communicative elements - in other words, tools that merge empirical research with participatory assessments and social learning - proved especially successful (Highlight 24). As sciencebased tools, they expand systems knowledge while simultaneously structuring and guiding communication and learning between researchers and societal actors. The approach also led to the development of exchange platforms between institutions and stakeholders (Highlights 19, 14), and local planning tools based on information technology and geographic information systems (Highlight 13).

\section{Consolidating and leveraging knowledge and data bases}

ESAPP's comprehensive database on sustainable land management and sustainable regional development includes geo-referenced long-term measurements and 
Table 1: ESAPP's analytical and communicative tools

ESAPP applied and further developed a set of innovative integrative tools that combine analytical and communicative components. Flexible and responsive, they are suited for multi-stakeholder interaction, and support continuous joint knowledge generation, knowledge and data sharing and re-use in societal and institutional learning within and beyond the partnership network. Many examples are provided in Ehrensperger et al, 2014:

- Sustainable Development Appraisal (SDA) structures participatory interaction between researchers and local people for the efficient generation of geo-referenced quantitative and qualitative information as a basis for planning and monitoring. It was applied, for example, during the establishment of the Simen Mountains World Heritage site in Ethiopia (Highlight 6).

- Learning for Sustainability (LforS) is an interactive tool that structures learning processes between researchers, representatives of local communities, as well as governmental and non-governmental institutions on urgent issues in the field. This is particularly relevant for conflict resolution and planning. It was used, for example, to help mitigate upstream-downstream water conflicts in the semi-arid areas of Kenya (Highlight 3), or natural resource use conflicts between different user and stakeholder categories in Mozambique (Highlight 24).

- ESAPP planning tools visualise quantitative and qualitative data within a specific context. Building on a reliable long-term database, they include geographic information systems (GIS) and remote sensing for dynamic modelling, as well as maps and rural advisory systems, to support informed communication, learning, and decision making in the fields and in offices. Data is made accessible in knowledge portals. Examples of how the ESAPP database is used include the Nakuru local urban observatory in Kenya (Highlight 13) or the development of the Ogiek Peoples Ancestral Territories Atlas (Highlight 7), the Socio-Economic Atlas of Kenya (Highlight 17), and the national-scale data catalogue for Ethiopia called EthioGis (Highlight 18).

- Complementary, actor-specific products were jointly developed and used in learning and negotiation processes between actors on local to national levels (books, thematic maps, comics, training modules, rural radio, and scientific publications). Examples include rural radio broadcasts in Madagascar and Kenya (Highlight 14).

observations of resources such as soils, water, and vegetation in diverse land use systems (Highlights 1-3). The database also reaches into the spheres of equity, livelihoods, and governance (Highlights 7-12, 19). It links ecological and socio-economic quantitative and qualitative knowledge at local, national, and regional levels, in places where global change is radically altering people's living conditions. The knowledge and database was a key asset for ESAPP in all its research, education and capacity development activities. Made accessible through knowledge portals, it continues to be the backbone for Southern partners and for research and policymaking in Eastern Africa (Highlights $13,17,18)$. The data have a high potential for complementing regional and global databases and observatories with context-specific bottom-up information. Such contextualised knowledge is indispensable for establishing adequate governance systems in Eastern and Southern Africa and helps ensure coherence among microto macrolevel governance approaches. This can benefit the Rio conventions, for example, which:

... individually and collectively, act as catalysts for action on adaptation at all levels. Remaining challenges to realising synergy between the Conventions can be overcome by employing appropriate planning tools such as ecosystembased approaches to adaptation and sustainable land management practices, in particular at the national and subnational level. (UNCBD/UNCCD/ UNFCCC, 2012, 15) 
Several ESAPP partner countries have formulated policies on sustainable land management and sustainable regional development (Ethiopian Strategic Investment Framework ESIF; Kenya Development Vision for 2030; 2025 Tanzanian 'kilimo kwanza' [agriculture first] policy; Agenda 2025 in Mozambique). Thus, ESAPP's knowledge and database will continue to serve the region's countries in their efforts to mitigate and adapt to rapid transformation processes far beyond the programme's lifetime.

\section{Challenges and way forward}

In conclusion, our study confirms the need for a democratisation of knowledge and knowledge generation for sustainable development. This requires that researchers assume a dual role at the science-policy interface: they must provide evidence by organising co-production of knowledge while simultaneously empowering actors and institutions within and outside academia as agents of change. Our study reveals how the Eastern and Southern Africa Partnership Programme as an early transdisciplinary endeavour organised its research along democratic and emancipatory principles. It functioned as what Dryzek and Stevenson (2011) call a deliberative system with transformative potential. Its three structural and procedural programme approaches provided an enabling framework for authentic, inclusive, and consequential deliberation (Dryzek, 2009). In communicative processes, the programme continuously expanded its deliberative capacity to enable democratised generation, brokerage, and use of knowledge; at the same time it secured meaningful participation, decision making, and Southern agency in research in a co-evolutionary process (Kemp et al, 2007) (Table 2). With respect to the global development agenda, ESAPP's research provided evidence-based contextualised knowledge and data for a coherent global environmental governance framework and strengthened contextualised capacities and institutions for sustainable development in Eastern and Southern Africa.The ESAPP experience confirms that normativity in the context of sustainable development is indeed very powerful in guiding development-oriented research.

Nonetheless, transdisciplinary research as a future-forming practice has its limitations. Generally, we must bear in mind that achievements in any open-ended process can only be procedural and gradual. Science-society interaction and learning processes strongly depend on contexts and on the commitment and capacities of the people involved. They take time, require substantial resources, and are often intangible, conflictual, and prone to partial failure. Transnational and transcultural research contexts add further dimensions to the complexity of science-policy interfaces and pose specific challenges. Experiences from ESAPP lead us to emphasise the following points:

- Established development policies and scientific culture are scarcely compatible with the experimental nature of sustainability research. Although promising ways of tackling stumbling blocks and trade-offs at the science-society interface are well-described (Wiesmann et al, 2011a; Sarkki et al, 2015) and were included in ESAPP's design, the programme's transdisciplinary implementation was continuously contested by partners within and beyond the programme.Tensions between the need for flexible and adaptive procedures and the mainstream cultures of science and development cooperation largely prevailed, as standard procedures and formats such as logframes thwart open-ended processes. A major lesson we learned is that transdisciplinary research practice requires particular investment 


\section{Table 2: Leverage points for a sustainability transformation in research for rural development}

\section{SUSTAINABLE LAND MANAGEMENT: key for securing ecosystem resilience}

Soils Soils are degrading

Jointly establish and share inventories on soils and context-specific land management that secure long-term resilience and multi-functionality of soils $\begin{array}{ll}\text { Water Water conflicts are increasing } & \begin{array}{l}\text { Promote awareness of limited water availability } \\ \text { and support user-driven governance institutions }\end{array}\end{array}$

Biodiversity Land resources are contested Ensure that local people benefit from protected areas and create spaces where humans and wildlife can coexist

\section{SUSTAINABLE REGIONAL DEVELOPMENT: key in linking local to global governance frameworks}

Equity

Livelihoods

Governance

Rural areas are rapidly transforming

Unreliable socio-political contexts are undermining rural development potentials

Contradictory customary, formal, and informal rights and claims trigger conflicts
Secure readiness of rural support systems by generating, visualising, and sharing information on social and economic disparities

Expand livelihood strategies within just and reliable legal frameworks

Disclose actors, dynamics, and decision-making powers and enhance subsidiary governance structures

KNOWLEDGE: key asset for Southern agency in rural development

Knowledge societies

Capacity development

Knowledge base

Social and economic
disparities increase alon
lines of knowledge and
structures
The agency of Southern
actors in development
initiatives is weak

A lack of contextualised knowledge is restricting initiatives' impacts
Promote the democratisation of knowledge, planning and decision making

Invest in human and institutional capacity development across all programme activities

Operate long-term databases and feed the data into rural support and monitoring systems and related observatories

FOUNDATIONS: must be equity-oriented

Sustainable

development

Transfer solutions fail to address structural causes of poverty

Partnerships

North-South research partnerships are commonly North-driven

Transdisciplinarity

Robust normative knowledge is gained in science-society interaction
Take leadership in enhancing equity and the inclusion of civil society in development initiatives

Establish and maintain long-term collaborative networks: they foster equity, shared understandings, and joint framing of new initiatives

Open up the process of knowledge generation, expand human and institutional capacity, and act as a knowledge broker

APPROACH: must be flexible and procedural

\section{Adaptive}

management

Dual structure Research for sustainable development is experimental but sustainability-oriented

Poverty alleviation needs often override sustainability concerns

Contextuality
The complexity of a rural development agenda is overwhelming
Provide stability and flexibility through a reflexive and partner-driven approach to research implementation

Combine action research with basic research and capacity development to advance innovative solutions and institutions coherent with local to global sustainable development

Identify and sequence context-specific action research projects as common ground for SouthSouth exchange and innovation 
and care in linking concepts and action. Consistent linkage of conceptual support and action research is of utmost interest, as it enhances human and institutional reflexive capacities and fosters the creation and the maintenance of a shared understanding of transdisciplinarity and sustainable development.

- Equity and inclusion are of particular concern in a complex North-South network such as ESAPP (Figure 1) (Upreti et al, 2011; Traynor et al, 2015; Stewart, 2015). But a devolution of power and an expansion of deliberative capacity are utterly impossible to achieve within the North-driven standard procedures, formats, and budgets - which, due to a lack of adequate evaluation, acceptance, or understanding of transdisciplinary work - still dominate the way in which development programmes are assessed and perceived. This also restricts legitimacy and accountability to both funding organisations and partners within and beyond the research network (Wiesmann et al, 2011a; Biermann and Gupta, 2011). The required institutional change calls for pragmatism or, in the words of Sneddon and colleagues:

... a middle and pragmatic path, one that takes seriously calls for radical changes in our ideas and institutions dealing with sustainable development, while also holding out the possibility that genuine reform of current institutions may be possible. $(2006,260)$

Indeed, ESAPP strategically built on leverage points within its procedural adaptive approach. We conclude, however, that equity concerns should be given broader and more rigorous attention.

A major strategic goal of ESAPP was to establish a well-functioning South-South research network capable of boosting research for sustainable development in Eastern Africa. But success has been limited. Differences in partners' institutional strengths, settings, and backgrounds, along with unstable political contexts (Eritrea and Madagascar) and weak anchoring in the respective country (Mozambique) proved to be major constraints on equity-based exchange already in the programme's lifetime. Low commitment and investment in weak partner countries resulted in a level of research activities that was insufficient to prove the work's relevance and enhance its visibility and acceptance. Success in these countries would require stable collaboration with local universities and research institutions. Support could also be provided through South-South exchange and collaboration; but in ESAPP's experience, Southern partners tend to shift between competition and cooperation, as national conditions and demands often override collaborative interests. This is even more the case for partners who are part of governmental institutions. While these partners may foster knowledge brokerage and evidence-informed decision making, governmental rationales often undermine both transnational collaboration and transdisciplinary concerns. We conclude that development actors and decision makers must invest particular attention and efforts in fostering the relevance and stability of South-South cooperation by ensuring that it is equitably and firmly embedded in all countries involved. 
Finally, we wish to note that the science-society interface in ESAPP's lifetime was fairly favourable. The programme enjoyed the support of advocates in science, policy, and society who had been inspired by the 1992 Earth Summit in Rio. Together, they engaged in framing and implementing research for sustainable development on a long-term co-evolutionary basis. This proved indispensable in addressing conflictual and sensitive issues with representatives of governments and civil society; examples include the joint identification of poverty indicators to be used for the Socio-Economic Atlas of Kenya (Wiesmann et al, 2014; Highlight 17), or the establishment of community organisations as acknowledged development partners in mitigating upstreamdownstream water conflicts (Highlight 3). ESAPP's long-term and co-evolutionary nature enabled the programme to develop the capacity - which its partner institutions have retained ever since - to provide support in urgent development needs arising in a highly dynamic context. On this basis, we advocate long-term contextualised collaboration as a much-needed counterculture and alternative to current technocratic and output-oriented mainstream practices, which do more harm than good. If we are to reach the sustainable development goals formulated in Agenda 2030, this spirit needs to be renewed at the science-policy interface. There is no alternative to equity-oriented transdisciplinary, reflexive, and co-evolutionary research partnerships in Africa - especially not in the context of current rapid economic growth, which is heightening pressure on natural resources and ecosystems, threatening rural livelihoods, and risks to widen rather than narrow socio-economic and political disparities. The success of development initiatives depends on the degree to which equity is viewed as a matter of access not only to natural resources but also to knowledge and knowledge generation.

\section{Acknowledgements}

This paper presents the authors' personal view. The authors would like to thank the Centre for Development and Environment (CDE) and all partners in the Eastern and Southern Africa Partnership Programme (ESAPP) for their assistance in reflecting on our long-term personal and institutional experience with transdisciplinary endeavours. In addition, we thank CDE for financial contributions that made it possible to develop the paper through presentations at a number of international sustainability fora, including the 2014 Norwich Conference on Earth System Governance: Access and Allocation in the Anthropocene, held on 1-3 July 2014 in Norwich, UK; the Ethics of Poverty Alleviation Conference, held on 28-29 August 2014 at the Centre for Ethics and Poverty Research, University of Salzburg, Austria; the 2015 Annual Conference of the European Forum on Studies of Policies for Research and Innovation (Eu-SPRI), on Innovation Policies for Economic and Social Transitions: Developing Strategies for Knowledge, Practices and Organizations, held on 10-12 June 2015 in Helsinki, Finland; and the 2015 Canberra Conference on Earth System Governance: Democracy and Resilience in the Anthropocene, held on 14-16 December 2015 in Canberra, Australia. The authors would like to thank the anonymous reviewers and the editors for their very supportive and insightful comments. 


\section{References}

Arocena, R, Göransson, B, Sutz, J, 2015, Knowledge policies and universities in developing countries: Inclusive development and the 'developmental university', Technology in Society 41, 10-20

Biermann, F, Gupta, A, 2011,Accountability and legitimacy in earth system governance: A research framework, Ecological Economics 70, 1856-64

Biermann, F, Betsill, MM, Gupta, J, Kanie, N, Lebel, L, Liverman, D, Schroeder, H, Siebenhüner, B, with contributions from Conca, K, da Costa Ferreira, L, Desai, B, Tay, S, Zondervan, R, 2009, Earth system governance: People, places and the planet: Science and implementation plan of the earth system governance project, Earth System Governance Report 1, IHDP Report 20, Bonn: IHDP Earth System Governance Project

Carter, K, Moir, S, 2012, Diagrammatic representations of sustainability:A review and synthesis, in Smith, SD (ed), Proceedings 28th Annual ARCOM Conference, 3-5 September, Edinburgh, 1479-89

Cash, DW, Borck, JC, Patt,AG, 2006, Countering the loading-dock approach to linking science and decision making: Comparative analysis of El Nino/Southern Oscillation (ENSO) forecasting systems, Science, Technology and Human Values 31, 465-94

Cornell, S, Berkhout, F, Tuinstra, W, Tàbara, JD, Jäger, J, Chabay, I, de Wit, B, Langlais, R, Mills, D, Moll, P, Otto, IM, Petersen, A, Pohl, C, van Kerkhoff, L, 2013, Opening up knowledge systems for better responses to global environmental change, Environmental Science \& Policy 28, 60-70

Dedeurwaerdere, T, 2014, Sustainability science for strong sustainability, Cheltenham: Edward Elgar

Dietz, T, Ostrom, E, Stern, PC, 2003, The struggle to govern the commons, Science $-302,1907-12$

Dryzek, JS, 2009, Democratization as deliberative capacity building, Comparative Political Studies 42, 11, 1379-1402

Dryzek, JS, Stevenson, H, 2011, Global democracy and earth system governance, Ecological Economics 70, 1865-74

Ehrensperger,A, Ott, C,Wiesmann, U (eds), 2015, Eastern and Southern Africa partnership programme: Highlights from 15 years of joint action for sustainable development, Bern: CDE and Bern Open Publishing, www.cde.unibe.ch/research/innovations_for_ sustainable_development/projects/esapp/esapp_highlights/index_eng.html

Gallopín, GC, Funtowicz, S, O’Connor, M, Ravetz, J, 2001, Science for the twentyfirst century: From social contract to the scientific core, International Social Science Journal 168, 219-29

Garud, R, Gehman, J, 2012, Metatheoretical perspectives on sustainability journeys: Evolutionary, relational and durational, Research Policy 41, 980-95

Gergen, KJ, 2015, From mirroring to world-making: Research as future forming, Theory of Social Behaviour 45, 3, 287-310

Haller, T, Acciaioli, G, Rist, S, 2016, Constitutionality: Conditions for crafting local ownership of institution-building processes, Society \& Natural Resources 29, 1, 68-87

Harding, S, 2012, Moving south and east: Epistemic modernization for global northern philosophies of science, Paper presented at the seminar: Relocating science and technology: Global knowledge, traveling technologies and postcolonialism, perspectives on science and technology studies in the global south, 19-20 July, Max-Planck-Institut für ethnologische Forschung, Halle an der Saale 
Head, BW, 2015, Towards more 'evidence-informed' policy making?, Public Administration Review 76, 3, 472-84

Hedlund-de Witt, A, 2014, Rethinking sustainable development: Considering how different worldviews envision 'development' and 'quality of life', Sustainability 6 , 8310-28

Hendriks, CM, 2009, Deliberative governance in the context of power, Policy $\mathcal{E}$ Society 28, 173-84

Hering, J, 2016, Do we need 'more research' or better implementation through knowledge brokering?, Sustainability Science 11, 2, 363-9

Higgins, K, Canavan, J, Coen, L, 2014, Mapping the field in evidence-informed policy and practice: International perspectives, Evidence \& Policy 10, 4, 489-95

Hirsch Hadorn, G, Bradley, D, Pohl, C, Rist, S, Wiesmann, U, 2006, Implications of transdisciplinarity for sustainability research, Ecological Economics 2006, 60, 119-28

Hirsch Hadorn, G, Hoffmann-Riem, H, Biber-Klemm, S, Grossenbacher-Mansuy, W, Joye, D, Pohl, C, Wiesmann, U, Zemp E (eds), 2008, Handbook of transdisciplinary research, Berlin: Springer

Hurni, H, Wiesmann, U, 2004, Towards transdisciplinarity in sustainability-oriented research for development, in Hurni, H,Wiesmann, U, Schertenleib, R (eds), Research for mitigating syndromes of global change, Perspectives of the Swiss National Centre of Competence in Research (NCCR) North-South, University of Bern, 1, Bern: Geographica Bernensia, 31-42

ISSC/UNESCO, 2013, World Social Science Report 2013: Changing global environments, Paris: OECD Publishing and UNESCO Publishing

gäger, J, 2009, The governance of science for sustainability, in Adger, WN, Jordan, A (eds), Governing sustainability, Cambridge: Cambridge University Press, 142-58

Kates, RW, Clark, WC, Corell, R, Hall, JM, Jeager, CC, Lowe, I, MacCarthy, JJ, Schellnhuber, HJ, Bolin, B, Dickson, NM, Faucheux, S, Gallopín, GC, Grübler, A, Huntley, B, Jaeger, J, Jodha, NS, Kasperson, ER, Mabogunje, A, Matson, P, Mooney, H, Moore, B III, O’Riordan, T, Svedin, U, 2001, Environment and development: Sustainability science, Science 292, 641-2

Kemp, R, Loorbach, D, Rotmans, J, 2007, Transition management as a model for managing processes of co-evolution towards sustainable development, International Journal of Sustainable Development \& World Ecology 14, 1, 78-91

Kläy, A, Zimmerman, AB, Schneider, F, 2014, Rethinking science for sustainable development: Reflexive interaction for a paradigm transformation, Futures 65, 72-85

Kristjanson, P, Reid, R, Dickson, N, Clark, W, Vishnubhotla, P, Romney, D, Bezkorowajnyj P, Said, M, Kaelo, D, Makui, O, Nkedianye, D, Nyangaga, J, Okwi, P, Puskur, R, Tarawali, S, MacMillan, S, Grace, D, Randolph, T, Affognon, H, 2008, Linking international agricultural research knowledge with action for sustainable poverty alleviation: What works?, CID Working Paper 173, Cambridge, MA: Harvard University and Nairobi: International Livestock Research Institute

Liverman, DM, 2009, Conventions of climate change: Constructions of danger and the dispossession of the atmosphere, Historical Geography 35, 279-96

Lövbrand, E, Stripple, J, Wiman, B, 2009, Earth system governmentality: Reflections on science in the Anthropocene, Global Environmental Change 19, 7-13

Lubchenco, J, 1998, Entering the century of the environment: A new social contract for science, Science 279, 5350, 491-7 
Mansilla,VB, Lamont, M, Kyoko Sato, K, 2012, The contributions of shared socioemotional-cognitive platforms to interdisciplinary synthesis, Paper presented at $4 \mathrm{~S}$ Annual Meeting,Vancouver, February 16-20, http://nrs.harvard.edu/urn-3:HUL. InstRepos:10496300

Mäder, U, Schassmann, H, 2012, Wie normativ muss die Armutsforschung sein?, Neue Praxis 42, 11, 18-29

Naustdalslid,J,2011, Climate change:The challenge of translating scientific knowledge into action, International Journal of Sustainable Development \& World Ecology 18, 3, 243-52

Nowotny, H, Scott, P, Gibbons, M, 2001, Re-thinking science: Knowledge and the public in an age of uncertainty, Cambridge: Polity

Olsson, P, Galaz, V, Boonstra, W, 2014, Sustainability transformations: A resilience perspective, Ecology \& Society 19, 4, 1

Ostrom, E, Janssen, MA, Anderies, JM, 2007, Going beyond panaceas, Proceedings of National Academy of Sciences 104, 39, 15176-8

Pindyck, SP, 2013, Climate change policy: What do the models tell us? Economic Literature 51, 3, 860-72

Pohl, C, Hirsch Hadorn, G, 2007, Principles for designing transdisciplinary research, München: Oekom Verlag

Pohl, C, van Kerkhoff, L, Bammer, G, Hirsch Hadorn, G, 2008, Integration, in Hirsch Hadorn, G, Hoffmann-Riem, H, Biber-Klemm, S, Grossenbacher-Mansuy, W, Joye, D, Pohl, C, Wiesmann, U, Zemp, E (eds), Handbook of transdisciplinary research, Dordrecht: Springer, 411-24

ProClim (Forum for Climate and Global Change), 1997, Research on sustainability and global change: Visions in science policy by Swiss researchers, Bern: Swiss Academy of Sciences

Rist, S, Chiddambaranathan, M, Escobar, C, Wiesmann, U, Zimmermann, A, 2007, Moving from sustainable management to sustainable governance of natural resources: The role of social learning processes in rural India, Bolivia and Mali, Rural Studies 23, 23-37

Sarkki, S, Tinch, R, Niemelä, J, Heink, U, Waylen, K, Timaeus, J, Young, J, Watt, A, Neßhöver, C, van den Hove, S, 2015,Adding 'iterativity' to the credibility, relevance, legitimacy:A novel scheme to highlight dynamic aspects of science-policy interfaces, Environmental Science and Policy 54, 505-12

Schroeder, H, 2014, Governing access and allocation in the Anthropocene, Global Environmental Change 26, A1-A3

Skoglund,A, Jensen,T,2013, The professionalization of ethics in the Intergovernmental Panel on Climate Change (IPCC): From servant of science to ethical master? Sustainable Development 21, 122-30

Sneddon, C, Howarth, RB, Norgaard, RB, 2006, Sustainable development in a postBrundtland world, Ecological Economics 57, 253- 68

Spangenberg,JH, 2011, Sustainability science:A review, an analysis and some empirical lessons, Environmental Conservation 38, 3, 275-87

Springett, D, 2005, Structural limits to sustainable development: Managers and progressive agency, International Journal of Innovation and Sustainable Development 1, $1 / 2,127-52$ 
Spruijt, P, Knol, AB, Vasileiadou E, Devilee, J, Lebret, E, Petersen, AC, 2014, Roles of scientists as policy advisers on complex issues: A literature review, Environmental Science and Policy 40, 16-25

Stewart, R, 2015, A theory of change for capacity building for the use of research evidence by decision makers in southern Africa, Evidence \& Policy 11, 4, 547-57

Sterman, JD, 2002, All models are wrong: Reflections on becoming a system scientist, System Dynamics Review 18, 4, 501-31

Stock, P, Burton, RJF, 2011, Review: Defining terms for integrated (multi-inter-transdisciplinary) sustainability research, Sustainability 3, 1090-1113

Stöckli, B,Wiesmann, U, Lys, JA, 2012, A guide for transboundary research partnerships: 11 principles and 7 questions, Bern: KFPE (Swiss Commission for Research Partnerships with Developing Countries), www.naturalsciences.ch/organisations/kfpe/11_ principles_7_questions

Tàbara, JD, Chabay, I, 2013, Coupling human information and knowledge systems with social-ecological systems change: Reframing research, education, and policy for sustainability, Environmental Science \& Policy 28, 71-81

Traynor, R, Dobbins, M, DeCorby, K, 2015, Challenges of partnership research: Insights from a collaborative partnership in evidence-informed public health decision making, Evidence \& Policy 11, 1, 99-109

Trenberth, K, 2010, Commentary: More knowledge, less certainty, Nature Reports Climate Change, 4, www.nature.com/climate/2010/1002/full/climate.2010.06.html

UN 2015, Transforming our world: The 2030 agenda for sustainable development, https://sustainabledevelopment.un.org/post2015/transformingourworld/ publication

UN-DESA, 2012, Back to our common future: Sustainable development in the 21st century (SD21) project, Summary for policymakers, https://sustainabledevelopment. un.org/content/documents/UN-DESA_Back_Common_Future_En.pdf

UNCBD/UNCCD/UNFCCC 2012, The Rio conventions: Action on adaptation, www.unccd.int/Lists/SiteDocumentLibrary/Publications/rio_20_adaptation_ brochure.pdf

UNDP, 2011, Human Development Report, Sustainability and equity: A better future for all, http://hdr.undp.org/sites/default/files/reports/271/hdr_2011_en_ complete.pdf

UNESCO, 2005, UNESCO World report: Toward knowledge societies, Paris: UNESCO UNESCO, 2010, UNESCOWorld social science report: Knowledge divides, Paris: UNESCO Upreti BR, Zimmermann AB, Berhanu, D, Cissé, G, 2011, Partnerships in developmentoriented research: Lessons learnt and challenges ahead, Kathmandu: NCCR North-South, South Asia Coordination office

Van den Hove, S, 2007, A rationale for science-policy interfaces, Futures 39, 807-26

Van Egmond, ND, de Vries, HJM, 2011, Sustainability: The search for the integral worldview, Futures 43, 853-67

VISION RD4SD (VISION Research and Development for Sustainable Development), 2013, Vision and Principles for harnessing RD4SD, http:// visionrd4sd.eu/?wpfb_dl=3

Waas, T, Hugé, J, Verbruggen, A, Wright, T, 2011, Sustainable development: A bird's eye view, Sustainability 3, 1637-61 
Warren, J, Garthwaite, K, 2015, Whose side are we on and for whom do we write? Notes on issues and challenges facing those researching and evaluating public policy, Evidence \& Policy 11, 2, 225-37

Welp, M, de la Vega-Leinert, A, Stoll-Kleemann, S, Jaeger, CC, 2006, Science-based stakeholder dialogues:Theories and tools, Global Environmental Change 16, 170-81

WBGU (German Advisory Council on Global Change), 2011, Flagship report: World in transition: A social contract for sustainability, Berlin: WBGU, www.wbgu. de/fileadmin/templates/dateien/veroeffentlichungen/hauptgutachten/jg2011/ wbgu_jg2011_en.pdf

WBGU, (German Advisory Council on Global Change), 2012, Research and education: Drivers of transformation, Factsheet 5, Berlin:WBGU, www.wbgu.de/en/factsheets/ factsheet-5/

WCED (World Commission on Environment and Development), 1987, Our common future, Oxford: Oxford University Press

Wiesmann, U, 1994, Gruppe für Entwicklung und Umwelt: Leitsätze zu Forschung und Umsetzung, Bern: Geographisches Institut der Universität Bern

Wiesmann, U, 1998, Sustainable regional development in rural Africa: Conceptual framework and case studies from Kenya, Bern: Geographica Bernensia

Wiesmann, U, Hurni, H, Ott, C, Zingerli, C, 2011a, Combining the concepts of transdisciplinarity and partnership in research for sustainable development, in Wiesmann, U, Hurni, H (eds, with an international group of co-editors), Research for sustainable development: Foundations, experiences, and perspectives, Perspectives of the Swiss National Centre of Competence in Research (NCCR) North-South, University of Bern, 6, Bern: Geographica Bernensia, 43-70

Wiesmann U, Ott, C, Ifejika Speranza, C, Kiteme, BP, Müller-Böker, U, Messerli, P, Zinsstag, J, 2011b, A human actor model as a conceptual orientation in interdisciplinary research for sustainable development, in Wiesmann, U, Hurni, H, (eds; with an international group of co-editors), Research for sustainable development: Foundations, experiences, and perspectives, Perspectives of the Swiss National Centre of Competence in Research (NCCR) North-South, University of Bern, 6, Bern: Geographica Bernensia, 231-56

Wiesmann, U, Kiteme, B, Mwangi, Z, 2014, Socio-economic atlas of Kenya: Depicting the national population census by county and sub-location, Nairobi: KNBS, Nanyuki: CETRAD, Bern: CDE 